\title{
CD49f-positive cell population efficiently enriches colon cancer-initiating cells
}

\author{
NAOTSUGU HARAGUCHI ${ }^{1}$, HIDESHI ISHII ${ }^{2}$, KOSHI MIMORI $^{3}$, KATSUYA OHTA $^{1}$, MAMORU UEMURA ${ }^{1}$, \\ JUNICHI NISHIMURA ${ }^{1}$, TAISHI HATA ${ }^{1}$, ICHIRO TAKEMASA ${ }^{1}$, TSUNEKAZU MIZUSHIMA ${ }^{1}$, \\ HIROFUMI YAMAMOTO $^{1}$, YUICHIRO DOKI ${ }^{1}$ and MASAKI MORI ${ }^{1}$
}

Departments of ${ }^{1}$ Gastroenterological Surgery and ${ }^{2}$ Frontier Science for Cancer and Chemotherapy, Graduate School of Medicine, Osaka University, Suita, Osaka 565-0871; ${ }^{3}$ Department of Surgery,

Kyushu University Beppu Hospital, Beppu, Oita 874-0838, Japan

Received February 7, 2013; Accepted April 2, 2013

DOI: $10.3892 /$ ijo.2013.1955

\begin{abstract}
Cancer stem cells (CSCs) also known as cancerinitiating cells (CICs) show high tumorigenic activity and high chemo- and radiation resistance. It is, therefore, important to identify CSCs reliably to develop novel curative cancer treatments. In this study, we re-evaluated CSC markers of colorectal cancer for their cellular differentiation and tumorigenic activity, with the aim to identify reliable CSC markers. The rates of change in CD44, CD133, CD166, CD24, CD49f and CXCR4 expression during sodium butyrate (NaBT)-induced cell differentiation were assessed in HT29 and Caco2 colon cancer cell lines. Expression levels of target markers were assessed in clinical CRC samples. Tumorigenic activity was assessed on isolated cell fractions identified by multicolor flow cytometric analysis. In the cell differentiation assay, the average percent change was higher in CD44 (-98.2\%) and CD49f (-74.4\%) compared to CD133 (-17.9\%) and CD166 (-49.4\%). Expression of CD24 and CXCR4 appeared random in HT29 and Caco2. Expression of CD44, CD49f, CD133 and CD166 was confirmed in all four clinical CRC samples. Limiting dilution assay of CD44- and CD133-expressing cells revealed that only the $\mathrm{CD} 133^{+} \mathrm{CD} 44^{+}$population possessed tumorigenic activity. Tumorigenesis was not affected by CD166 expression. Highly tumorigenic cells could be enriched in samples with higher CD49f expression; $\mathrm{CD} 49 \mathrm{f}^{+}$cells showed high tumorigenesis, whereas $\mathrm{CD}_{133^{+}}$and $\mathrm{CD} 44^{+}$cells that were negative for CD49f exhibited no tumorigenic activity. Multicolor analysis revealed that $\mathrm{CD} 49 \mathrm{f}^{+}$cells localized in $\mathrm{CD} 44^{+}$and $\mathrm{CD} 133^{+}$ cell fractions. These findings demonstrated that CD49f is an important marker for identifying colorectal CSCs and suggest that the $\mathrm{CD}_{4} 9 \mathrm{f}^{+}$cell fraction may be the best candidate for colorectal CSCs.
\end{abstract}

Correspondence to: Professor Masaki Mori, Department of Gastroenterological Surgery, Graduate School of Medicine, Osaka University, Suita, Yamadaoka 2-2, Osaka 565-0871, Japan

E-mail: mmori@gesurg.med.osaka-u.ac.jp

Key words: surface markers, CD44, CD49f, colon cancer, coloncancer-initiating cells

\section{Introduction}

Cancer stem cells (CSCs) possess ability to self renew, high tumorigenic activity, resistance to anticancer drugs and radiation and cause cancer recurrence (1-4). Successful targeting of CSCs is believed to lead to development of curative cancer therapy. The presence of CSCs has been detected in colorectal cancers (CRCs) and CD133, CD44, CD166, CD24 and ALDH expressing cells have been reported as CSC candidates in CRC (5-11). Though numerous markers have been identified as candidates for CSCs as the study of CSC has progressed, few reports have confirmed the presence of these markers. The development of CSC therapies will require identifying CSC markers that reliably identify CSCs.

CSCs have been reported to possess high metastatic ability in various cancers (12-15). The assessment of markers for cancer cell metastasis might also be important for the study of CSC in CRC. CD49f, also known as integrin $\alpha 6$ (ITGA6), is reportedly associated with tumor cell invasion and metastasis in CRC (16-21). The chemokine receptor CXCR4 plays a critical role in cancer cell metastasis via stromal interaction and hypoxia-related pathways $(12,22-26)$. To isolate CSCs in CRC, we focused on the changes in markers during cell differentiation, given that CSCs construct a cancer-cell society in a hierarchical manner by producing differentiated cancer cells. Forced cell differentiation leads to depletion of CSCs and results in the decay of the cancer cell hierarchy in brain tumors and colon cancer (27-30). Thus, adaptation of cell differentiation assay is useful for the isolation of immaturecell phenotypes (31). In this study, with the aim of identifying CSC markers, we assessed changes in expression levels of known CSC markers of CRC- and metastasis-associated markers induced during cell differentiation. Using serial transplantation of clinical CRC samples, we also assessed the tumorigenic activity of isolated cell fractions to determine whether they exhibited self-renewal activity.

\section{Materials and methods}

Tumor cell preparation and cell culture. HT29 was cultured in McCoy's medium 5A (Invitrogen)/10\% fetal bovine serum 
(FBS; Equitech-Bio) with $2 \mathrm{mM}$ L-glutamine (Invitrogen), $100 \mu \mathrm{g} / \mathrm{ml}$ penicillin $\mathrm{G}$ and $100 \mathrm{U} / \mathrm{ml}$ streptomycin (Invitrogen). Caco2 was cultured in RPMI-1640 (Invitrogen)/10\% FBS with $100 \mu \mathrm{g} / \mathrm{ml}$ penicillin $\mathrm{G}$ and $100 \mathrm{U} / \mathrm{ml}$ streptomycin. HT29 was obtained from the American Type Culture Collection (ATCC) and Colo201 was obtained from the Japanese Collection of Research Bioresources Cell Bank (JCRB). The clinical colorectal cancer samples were obtained from Kyushu University at Beppu and Osaka University upon patients' informed consent and approval by the Research Ethics Board at Kyushu University and Osaka University in Japan.

Sodium butyrate treatment and alkaline phosphatase assay. Cell differentiation was induced with sodium butyrate (NaBT; Wako) as previously reported (31). Briefly, HT29 and Caco2 cells were dissociated with $0.25 \%$ trypsin and $0.02 \%$ EDTA and $1 \times 10^{6}$ cells were subsequently seeded into $10-\mathrm{cm}$ plastic flasks (BD; Becton-Dickinson). The next day, $5 \mathrm{mM}$ sodium butyrate (NaBT; Wako) was added and the culture was incubated for $72 \mathrm{~h}$. The expression level of alkaline phosphatase was determined by ELISA with SensoLyte ${ }^{\mathrm{TM}}$ pNPP Alkaline Phosphatase Assay kit (AnaSpec) according to the manufacturer's protocol.

Transplantation of human colon cancer cells into NOD/ SCID mice. Colon cancer cells obtained from three independent patients were suspended in a 1:1 mixture of media and basement membrane matrix high concentration (BD; BectonDickinson) and inoculated subcutaneously into the axillary and inguinal regions of NOD/SCID mice (5 weeks of age) under anesthesia. After 8-12 weeks, tumors were removed and analyzed by flow cytometry as described below. All of the xenograft lines were originally implanted into NOD/SCID mice subcutaneously and not cultivated or expanded in vitro. To study the tumorigenic activity of isolated cell populations, cell doses of $1 \times 10^{4}$ and $5 \times 10^{3}$ of cells were inoculated into the axillary and inguinal regions, respectively, of NOD/SCID mice. Tumorigenicity was evaluated 6 weeks after NOD/SCID transplantation.

Digestion of cancer tissues. Colon cancer tissues were minced with a sterile scalpel, washed twice with DMEM/10\% FBS with $100 \mu \mathrm{g} / \mathrm{ml}$ penicillin $\mathrm{G}$ and $100 \mathrm{U} / \mathrm{ml}$ streptomycin (Invitrogen) and placed in DMEM/10\% FBS with $2 \mathrm{mg} / \mathrm{ml}$ collagenase A (Roche) solution. The mixture was incubated at $37^{\circ} \mathrm{C}$ for $\leq 2 \mathrm{~h}$ to allow complete digestion. Every $15 \mathrm{~min}$, the solution was mixed in a $10-\mathrm{ml}$ pipette to encourage dissociation. Cells were filtered through 40- $\mu \mathrm{m}$ nylon mesh and washed twice and cell fragments and debris were subsequently eliminated by Ficoll (GE Healthcare) density gradient centrifugation. Cells were stained for flow cytometry or subsequent transplantation into NOD/SCID mice.

Flow cytometric analysis and cell sorting. To characterize colon cancer-initiating cells, the following antibodies were used: APC- or PE-conjugated anti-human CD133/1 (clone AC133, mouse IgG2a, Miltenyi-Biotec), FITC- or PE-conjugated anti-human CD44 (clone G44-26, mouse IgG2b, BD), FITC- or PE-conjugated anti-human CD49f (clone GoH3, Rat IgG2a, BD), FITC-conjugated anti-human
CD166 (clone N6B6, mouse IgG2a, BD), FITC-conjugated anti-human CD24 (clone ML5, mouse IgG2a, BD) and PE-Cy7-conjugated anti-human CXCR4 (CD184; clone 12G5, mouse IgG2a, BD).

To isolate human cells from mouse xenografts, biotinylated anti-mouse $\mathrm{H}-2 \mathrm{~K}^{\mathrm{d}}$ (clone SF1-1.1, mouse IgG2a, BD) and biotinylated anti-mouse CD45 (clone 30-F11, mouse IgG2b, BD) were used. Streptavidin-conjugated APC-Cy7 (BD) was used as secondary antibody. Doublet cells were eliminated with FSC-A/FSC-H and SSC-A/SSC-H. Dead and dying cells were eliminated with 7-amino-actinomycin D (7-AAD; BD). Samples were analyzed and sorted with BD FACSAria II flow cytometer (Becton-Dickinson) and data were analyzed with Diva software (Becton-Dickinson).

\section{Results}

Screening of colorectal cancer stem cell markers by differentiation assay. To assess whether representative CSC markers were in fact associated with cell differentiation, we applied sodium butyrate (NaBT) cell differentiation assay to HT29 and Caco2 (31-33). We assessed the expression of CD44 (8), CD133 (5,6,9), CD166 (8) and CD24 (9) before and after the NaBT treatment. We also assessed CD49f and CXCR4 expression, because CD49f was reported as a marker of breast (34), prostate (35) and glioblastoma (36) CSCs and CXCR4 was reported to be a marker of pancreas CSCs (12). CD49f and CXCR4 is also known to deeply associate with cancer metastasis $(12,16-26)$. The expression of CD44 was drastically reduced by $\mathrm{NaBT}$ treatment (rate of change, $-99.2 \%$ in HT29 and $-97.2 \%$ in Caco2; average, -98.2\%). Expression of CD49f was also reduced by NaBT treatment $(-73.7 \%$ in HT29 and $-75.0 \%$ in Caco2; average, $-74.4 \%$ ). The percent change in CD133 expression was not significantly high (-26.0\% in HT29 and $-9.8 \%$ in Caco2; average, $-17.9 \%$ ) compared to those of CD44 and CD49f. The expression of CD166 was markedly reduced in HT29 (-82.7\%) but not in $\mathrm{Caco} 2(-16.0 \%)$. The expression of CXCR4 was slightly reduced by NaBT treatment $(-8.4 \%$ in HT29, $-10.0 \%$ in Caco2; average, $-9.2 \%)$. The expression of CD24 was slightly reduced in HT29 (-15.2\%), but significantly increased in Caco2 $(+431.0 \%)$ (Table I). We focused on CD49f in subsequent studies because its expression was sharply altered by NaBT treatment in both HT29 and Caco2.

Flow cytometric analysis of primary colon cancer cells. Expression levels of representative colorectal CSC markers (CD44, CD133 and CD166) and the candidate marker CD49f were confirmed in four cases of primary colon cancer by flow cytometry. Tumor cells were obtained independently from mouse xenografted clinical colorectal cancer cells. The expression of CD44 and CD133 were $30.3 \pm 14.0$ and $35.5 \pm 14.7 \%$, respectively. Double staining of CD44 and CD133 indicated that tumor cells were constructed by $\mathrm{CD} 44^{+} \mathrm{CD} 133^{+}$, $\mathrm{CD}_{4}{ }^{+} \mathrm{CD} 133^{-}, \mathrm{CD}_{4} 4^{-} \mathrm{CD} 133^{+}$and $\mathrm{CD}^{-} 4^{-} \mathrm{CD} 133^{-}$cell fractions, as we previously reported (31). CD49f-expressing cells $(8.0 \pm 2.6 \%)$ were localized in the $\mathrm{CD}_{4} 4^{+}$and $\mathrm{CD} 133^{+}$cell fractions. CD166-expressing cells $(7.0 \pm 3.4 \%)$ were also localized in the $\mathrm{CD} 44^{+}$cell fraction but were present in both CD133-positive and -negative fractions. Double staining of 
Table I. Changes in positive ratios of cell surface markers following NaBT-induced differentiation.

\begin{tabular}{|c|c|c|c|c|c|c|c|}
\hline \multirow[b]{2}{*}{ Marker } & \multicolumn{3}{|c|}{ HT29 } & \multicolumn{3}{|c|}{$\mathrm{Caco} 2$} & \multirow[b]{2}{*}{$\begin{array}{l}\text { Average of rate } \\
\text { of change }(\%)\end{array}$} \\
\hline & $\begin{array}{c}\text { Control } \\
(\%)\end{array}$ & $\begin{array}{c}\mathrm{NaBT} \\
\text { treat }(\%)\end{array}$ & $\begin{array}{c}\text { Rate of } \\
\text { change }(\%)\end{array}$ & $\begin{array}{c}\text { Control } \\
(\%)\end{array}$ & $\begin{array}{c}\mathrm{NaBT} \\
\text { treat }(\%)\end{array}$ & $\begin{array}{c}\text { Rate of } \\
\text { change }(\%)\end{array}$ & \\
\hline CD44 & 77.8 & 0.6 & -99.2 & 14.2 & 0.4 & -97.2 & $-98.2 \%$ \\
\hline CD133 & 90.1 & 67.7 & -26.0 & 93.6 & 84.4 & -9.8 & $-17.9 \%$ \\
\hline CD49f & 99.9 & 26.3 & -73.7 & 32.8 & 8.3 & -75.0 & $-74.4 \%$ \\
\hline CD166 & 49.2 & 8.5 & -82.7 & 55.4 & 46.7 & -16.0 & $-49.4 \%$ \\
\hline CD24 & 97.2 & 82.4 & -15.2 & 6.2 & 32.9 & 431.0 & $+207.9 \%$ \\
\hline CXCR4 & 40.7 & 37.3 & -8.4 & 1.0 & 0.9 & -10.0 & $-9.2 \%$ \\
\hline
\end{tabular}

A
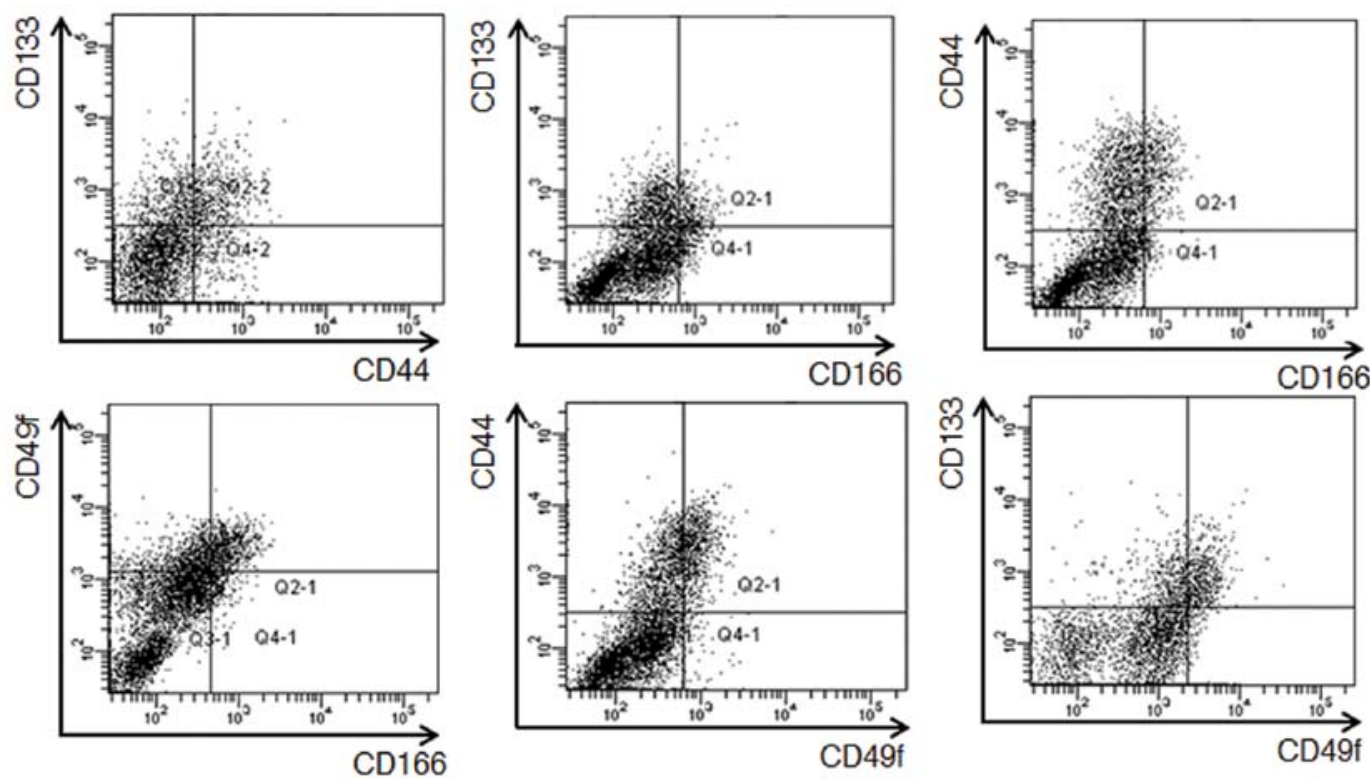

B

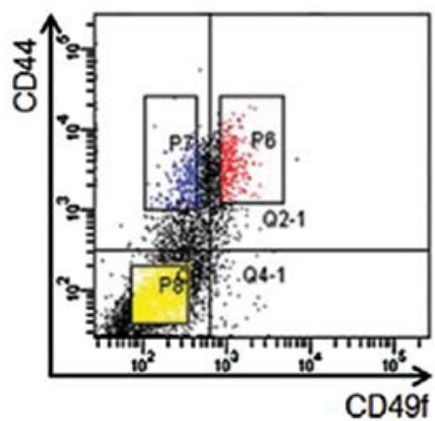

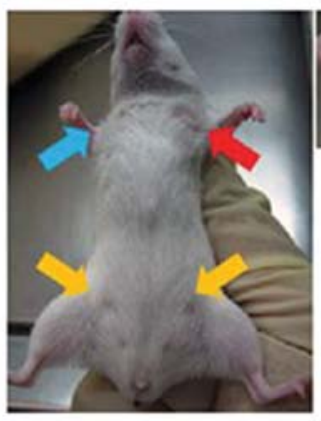

CD49f-CD44-

Figure 1. CD49f ${ }^{+} \mathrm{CD} 44^{+}$cell fraction shows high tumorigenic activity in NOD/SCID mice. (A) Representative expression patterns of CD44, CD133, CD166 and CD49f in clinical CRC samples. (B) A combined analysis with CD49f and CD44 revealed three populations of CD49f ${ }^{+} \mathrm{CD} 44^{+}(\mathrm{P} 6), \mathrm{CD} 49 \mathrm{fCD} 44^{+}(\mathrm{P} 7)$ and CD49f CD44 (P8). An aliquot of $5 \times 10^{4}$ cells of isolated $\mathrm{CD} 49 \mathrm{f}^{+} \mathrm{CD} 44^{+}, \mathrm{CD} 49 \mathrm{f}^{-} \mathrm{CD} 44^{+}$and $\mathrm{CD} 49 \mathrm{f}^{-} \mathrm{CD} 44^{-}$cells obtained from xenografted clinical CRC in NOD/SCID mice were transplanted subcutaneously into secondary NOD/SCID mice. Each arrow shows the injected area. Note that only CD49f+CD44+ ${ }^{+}$cells formed a tumor in NOD/SCID mice.

CD49f and CD166 indicated that tumor cells could be divided

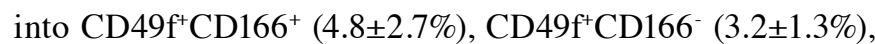

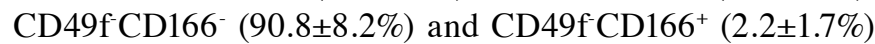
cell fractions (Fig. 1A).
Tumorigenic activity in NOD/SCID mouse. To assess the tumorigenic and self-renewal activities of isolated tumor cell fractions, we applied a serial transplantation technique. As reported previously (31), the CD133-CD44- and CD133+CD44- 
A
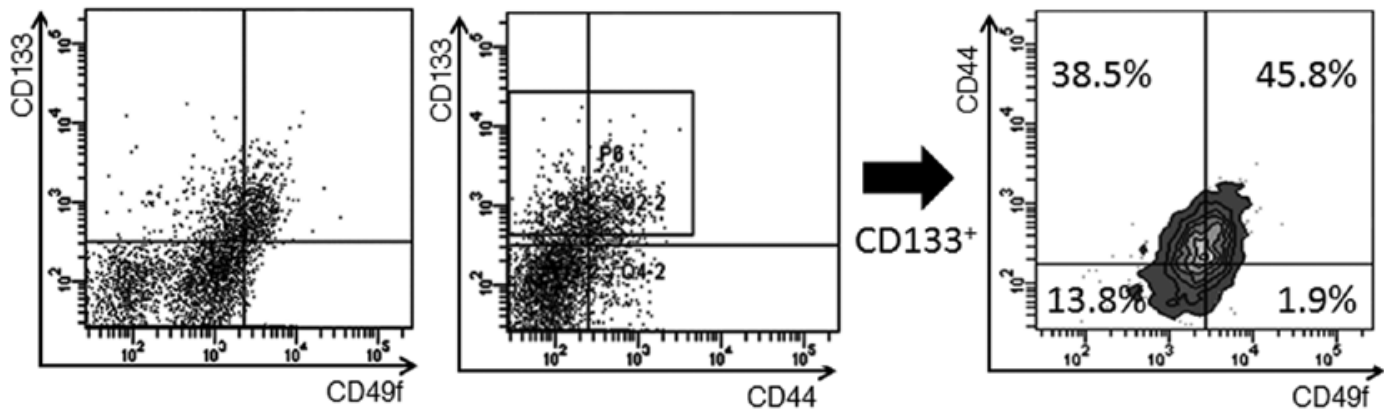

B
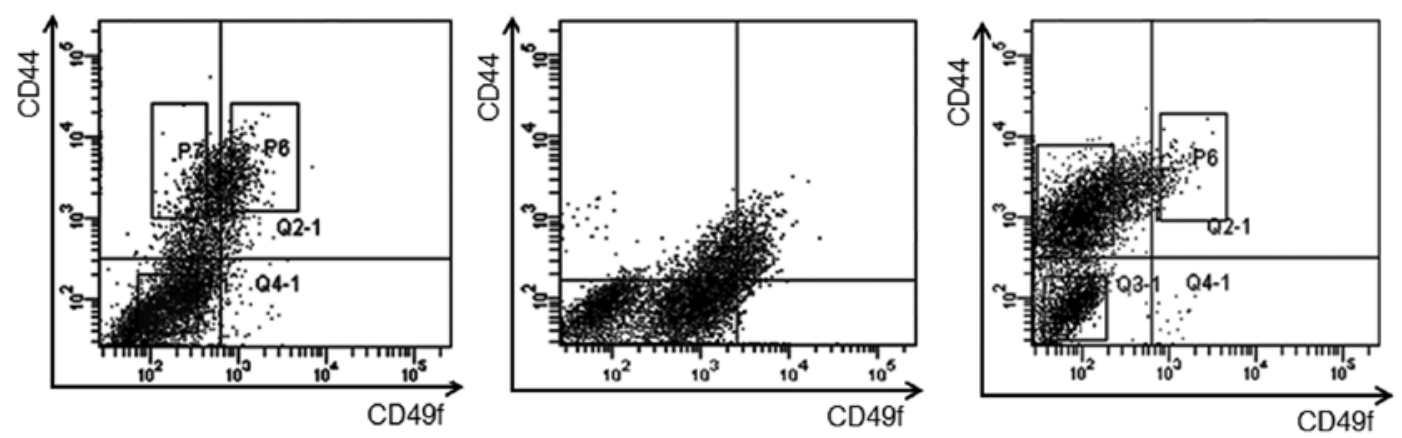

Figure 2. CD49f-expressing cells localize in CD133- and CD44-positive cell fractions. (A) A combined analysis of CD49f, CD44 and CD133 expression in a representative clinical CRC sample. Analysis showed that CD133 expressing cells could be divided into four cell fractions by staining with CD44 and CD49f; $\mathrm{CD} 49 \mathrm{f}^{+} \mathrm{CD} 44^{+}, \mathrm{CD} 49 \mathrm{f} \mathrm{CD} 44^{+}, \mathrm{CD} 49 \mathrm{f}^{-\mathrm{CD}} 44^{-}$and a very small fraction of $\mathrm{CD} 49 \mathrm{f}^{+} \mathrm{CD} 44$. (B) A NOD/SCID xenografted line was digested and analyzed by flow cytometry. Association of CD44 and CD49f expression were analyzed for three cases of xenografted CRC samples. CD49f-expressing cells were localized in the CD44-positive cell fraction.

fractions formed no tumors, whereas only the $\mathrm{CD} 133^{+} \mathrm{CD} 44^{+}$ fraction formed a tumor $\left(3 / 3\right.$ cases in $1 \times 10^{4}$ cells and $3 / 4$ cases in $5 \times 10^{3}$ cells), suggesting that CD44 has a more important role in tumorigenic activity than CD133. Expression of CD166 led to no difference in tumorigenicity; both CD166-positive and -negative cells formed tumors when they expressed CD133 or CD44. But the rate of tumor formation at the cell dose of $5 \times 10^{3}$ was lower in the $\mathrm{CD} 133^{+}$fraction to some extent $\left(\mathrm{CD}_{133}{ }^{+} \mathrm{CD}^{+66} 6^{+} ; 1 / 3 ; 33.3 \%\right)$ compared to that of $\mathrm{CD} 44^{+}$fraction $\left(\mathrm{CD} 44^{+} \mathrm{CD} 166^{+} ; 2 / 3 ; 66.7 \%\right)$, also suggesting that $\mathrm{CD} 44$ is more closely associated with tumorigenicity than CD133. Next, the tumorigenic activity of CD49f-expressing cells was

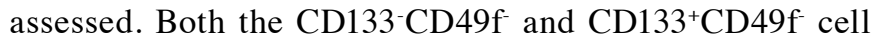
fractions formed no tumors, whereas the $\mathrm{CD} 133^{+} \mathrm{CD} 49 \mathrm{f}^{+}$ cell fraction formed tumors at cell doses of $1 \times 10^{4}$ and $5 \times 10^{3}$. Combined analysis of CD49f with CD44 revealed that only $\mathrm{CD} 44^{+} \mathrm{CD} 49 \mathrm{f}^{+}$fraction formed tumors at the cell doses of $1 \times 10^{4}$ and $5 \times 10^{3}$. CD44-CD49f ${ }^{-}$and $\mathrm{CD} 44^{+} \mathrm{CD} 49 \mathrm{f}^{-}$fraction formed no tumors (Fig. 1B and Table II). Expression of CXCR4 did not affect the tumorigenicity $\left(3 / 3\right.$ in both $1 \times 10^{4}$ and $5 \times 10^{3}$; data not shown).

Expression analysis of CD133, CD44 and CD49f. The associations of expression of CD133 with CD49f and of CD44 with $\mathrm{CD} 49 \mathrm{f}$ were assessed in primary colon cancer cells. Expression analysis of $\mathrm{CD} 49 \mathrm{f}$ and $\mathrm{CD} 133$ revealed that $52.3 \%$ of $\mathrm{CD} 49 \mathrm{f}^{+}$ cells co-expressed CD133, whereas $47.7 \%$ of $\mathrm{CD}^{2} 33^{+}$cells were negative for CD49f (Fig. 2A). A combined analysis of CD49f,
Table II. Tumor-initiating ability of the cell populations.

\begin{tabular}{|c|c|c|}
\hline Cell population & 10,000 cells & 5,000 cells \\
\hline $\mathrm{CD} 133^{-} \mathrm{CD} 44^{-}$ & (-) $0 / 3$ & (-) $0 / 4$ \\
\hline $\mathrm{CD} 133^{+} \mathrm{CD} 44^{-}$ & $(-) 0 / 3$ & (-) $0 / 4$ \\
\hline $\mathrm{CD} 133^{+} \mathrm{CD} 44^{+}$ & (+) $3 / 3$ & (+) $3 / 4$ \\
\hline $\mathrm{CD}^{-} 3^{-\mathrm{CD}} 16^{-}$ & $(-) 0 / 3$ & $(-) 0 / 3$ \\
\hline $\mathrm{CD} 133^{+} \mathrm{CD} 166^{-}$ & (+) $3 / 3$ & (+) $1 / 3$ \\
\hline $\mathrm{CD} 133^{+} \mathrm{CD} 166^{+}$ & (+) $3 / 3$ & (+) $1 / 3$ \\
\hline $\mathrm{CD} 44^{-} \mathrm{CD} 166^{-}$ & (-) $0 / 3$ & (-) $0 / 3$ \\
\hline $\mathrm{CD} 44^{+} \mathrm{CD} 166^{-}$ & (+) $3 / 3$ & (+) $2 / 3$ \\
\hline $\mathrm{CD}_{44}{ }^{+} \mathrm{CD} 166^{+}$ & (+) $3 / 3$ & (+) $2 / 3$ \\
\hline CD133-CD49f- & $(-) 0 / 4$ & $(-) 0 / 4$ \\
\hline $\mathrm{CD} 133^{+} \mathrm{CD} 49 \mathrm{f}^{-}$ & $(-) 0 / 4$ & $(-) 0 / 4$ \\
\hline $\mathrm{CD} 133^{+} \mathrm{CD} 49 \mathrm{f}^{+}$ & (+) $3 / 4$ & (+) $6 / 8$ \\
\hline $\mathrm{CD} 44^{-\mathrm{CD}} 49 \mathrm{f}^{-}$ & $(-) 0 / 4$ & $(-) 0 / 6$ \\
\hline $\mathrm{CD}_{4} 4^{+} \mathrm{CD} 49 \mathrm{f}^{-}$ & $(-) 0 / 4$ & $(-) 0 / 6$ \\
\hline $\mathrm{CD} 44^{+} \mathrm{CD} 49 \mathrm{f}^{+}$ & (+) $4 / 4$ & (+) $6 / 8$ \\
\hline
\end{tabular}

CD44 and CD133 revealed that the $\mathrm{CD} 133^{+}$cells contained $45.8 \%$ of $\mathrm{CD} 49 \mathrm{f}^{+} \mathrm{CD} 44^{+}$cells, $38.5 \%$ of $\mathrm{CD} 49 \mathrm{f}^{-} \mathrm{CD} 44^{+}$cells, $13.8 \%$ of $\mathrm{CD}^{4} \mathrm{f}^{-\mathrm{CD}} 44^{-}$cells and a very small number of CD49f ${ }^{+} \mathrm{CD}_{4}^{-}$cells (Fig. 2A). 
Expression of CD49f was confirmed in each of the three cases of primary colon cancer and the percentage of CD49f $\mathrm{f}^{+}$ cells in $\mathrm{CD}_{4} 4^{+}$cells ranged from 8.5 to $50.2 \%(30.5 \pm 20.9 \%)$. The $\mathrm{CD}_{4} 4^{+}$cell fraction was divided into $\mathrm{CD} 44^{+} \mathrm{CD} 49 \mathrm{f}^{+}$and CD $44^{+} \mathrm{CD} 49 \mathrm{f}^{-}$fractions, but CD $49 \mathrm{f}^{+}$cells were localized in the $\mathrm{CD} 44^{+}$cell fraction in each of the three cases (Fig. 2B). In view of the finding that both $\mathrm{CD} 133^{+} \mathrm{CD} 49 \mathrm{f}^{+}$cells and $\mathrm{CD} 44^{+} \mathrm{CD} 49 \mathrm{f}^{+}$cells possess tumorigenic activity and that CD $49 \mathrm{f}^{+}$cells localized in the $\mathrm{CD} 133^{+}$and $\mathrm{CD} 44^{+}$cell fractions, $\mathrm{CD}_{49 \mathrm{f}^{+}}$cells may be the best candidate for colorectal CSCs.

\section{Discussion}

This study demonstrated that CD49f is an important marker for efficient enrichment of colorectal CSCs. In colorectal cancer, $\mathrm{CD} 44^{+}, \mathrm{CD}_{133^{+}}, \mathrm{CD} 166^{+}, \mathrm{CD} 24^{+}$and aldehyde dehydrogenase (ALDH)-positive cells have been reported as a candidate for colorectal CSCs (5-11). This study aimed to identify novel and definitive CSCs markers in CRC by evaluation of the tumor-initiation efficiency of known and candidate CSCs. To achieve this purpose, we applied cell differentiation and serial transplantation assays. Similar to normal stem cells, CSCs possess self-renewal ability and produce differentiated cells in the cancer cell hierarchy. It is reported that bone morphogenetic proteins (BMPs) induce cell differentiation in colorectal CSCs (30) and in brain tumor-initiating cells $(28,29)$. Because the content of such immature cell phenotypes will decrease during cellular differentiation process, it is reasonable to assess the rate of change of cell surface markers for identification and evaluation of candidate CSC markers. One method for inducing for cancer cell differentiation is the use of NaBT (31-33). In the assessment of two CRC cell lines, the expression levels of both CD44 and CD49f were sharply decreased after the forcing of cell differentiation with NaBT. That the expression of CD133 and CD166 was not much altered by cell differentiation compared to CD44 and CD49f suggested that CD44 and CD49f are enriched in the immature cell fraction more than CD133 and CD166. This result is partly supported by a report that CD44 may be more suitable as a cancer-initiating cell marker than CD133 (8). The expression of CD24 and CXCR4 appeared random in HT29 and Caco2.

Assessment of self-renewal activity is important for confirmation of the stemness of an isolated cell fraction (1-4). By the use of cell materials from xenografted primary colon cancers for tumorigenic assessment, it is relatively easy to assess the self-renewal ability of targeted cell populations. In our experiments, tumors formed in immunodeficient mice invariably re-form tumors in serially transplanted syngenic mice (31). Thus, absence of tumor formation in a given isolated cell population indicates the loss of self-renewal activity of this isolated cell fraction. In the tumorigenic assessment, CD49f displayed promising ability for tumorigenic cell enrichment; CD $44^{+}$or $\mathrm{CD} 133^{+}$ cells exhibited no tumorigenic activity when they were negative for CD49f expression. In the expression analysis, $\mathrm{CD}_{49 \mathrm{f}^{+}}$cells were localized in the $\mathrm{CD} 44^{+}$and $\mathrm{CD} 133^{+}$cell fractions. In our previous report (31) and in this study, we have confirmed that $\mathrm{CD} 44^{+} \mathrm{CD} 133^{+}$cells are tumor-initiating cells. The $\mathrm{CD} 44^{+} \mathrm{CD} 133^{+}$cell fraction contained $38.5 \%$ of CD49f ${ }^{-}$cells and $45.8 \%$ of $\mathrm{CD}^{4} 4^{+}$cells. These results suggest that $\mathrm{CD}_{49 \mathrm{f}^{+}}$cells may be the best candidates for CSCs and tumor-initiating cells in CRC.

CD49f, also known as integrin $\alpha 6$ (ITGA6), is a major laminin receptor and mediates cell adhesion $(16,18,19,21)$. In colon cancer, expression of CD49f has been reported to be associated with tumor cell invasion and metastasis via integrin-mediated cell signaling and adhesion to the extracellular matrix $(16,18,19,21)$. CSCs in various cancers show high metastatic potency (12-15). In the liver metastasis model of CRC cells, it is reported that $\alpha 6$-integrin expression on circulating CRC cells mediates cell adhesion in hepatic microcirculation and extravasation into liver parenchyma (18). In addition, inhibition of CD49f by specific antibody resulted in reduction of cancer cell extravasation and migration (21). Successful targeting of CD49f-expressing cells may contribute to the development of a novel radical cancer treatment. Of course, it is necessary to assess if the inhibition of CD $49 \mathrm{f}^{+}$cells actually disintegrates the cancer cell hierarchy via suppression of self-renewal activity. It will also be necessary to assess the metastatic activity of CD49f expressing cells in a future study, given that we could not identify metastatic lesions in the term of this study using subcutaneous transplantation.

\section{Acknowledgements}

This study was supported by a Grant-in-Aid for Young Scientists (Start-up) from the Japan Society for the Promotion of Science (23800039) and by a Grant-in-Aid for Young Scientists from the Yasuda Medical Foundation.

\section{References}

1. Lapidot T, Sirard C, Vormoor J, et al: A cell initiating human acute myeloid leukaemia after transplantation into SCID mice. Nature 367: 645-648, 1994.

2. Singh SK, Hawkins C, Clarke ID, et al: Identification of human brain tumour initiating cells. Nature 432: 396-401, 2004.

3. Kim CF, Jackson EL, Woolfenden AE, et al: Identification of bronchioalveolar stem cells in normal lung and lung cancer. Cell 121: 823-835, 2005.

4. Pardal R, Clarke MF and Morrison SJ: Applying the principles of stem-cell biology to cancer. Nat Rev Cancer 3: 895-902, 2003.

5. O'Brien CA, Pollett A, Gallinger S and Dick JE: A human colon cancer cell capable of initiating tumour growth in immunodeficient mice. Nature 445: 106-110, 2007.

6. Ricci-Vitiani L, Lombardi DG, Pilozzi E, Biffoni M, Todaro M, Peschle $\mathrm{C}$ and De Maria R: Identification and expansion of human colon-cancer-initiating cells. Nature 445: 111-115, 2007.

7. Ieta K, Tanaka F, Haraguchi N, et al: Biological and genetic characteristics of tumor-initiating cells in colon cancer. Ann Surg Oncol 15: 638-648, 2007.

8. Dalerba P, Dylla SJ, Park IK, et al: Phenotypic characterization of human colorectal cancer stem cells. Proc Natl Acad Sci USA 104: 10158-10163, 2007.

9. Vermeulen L, Todaro M, de Sousa Mello F, et al: Single-cell cloning of colon cancer stem cells reveals a multi-lineage differentiation capacity. Proc Natl Acad Sci USA 105: 13427-13432, 2008.

10. Huang EH, Hynes MJ, Zhang T, et al: Aldehyde dehydrogenase 1 is a marker for normal and malignant human colonic stem cells (SC) and tracks SC overpopulation during colon tumorigenesis. Cancer Res 69: 3382-3389, 2009.

11. Todaro M, Francipane MG, Medema JP and Stassi G: Colon cancer stem cells: promise of targeted therapy. Gastroenterology 138: 2151-2162, 2010. 
12. Hermann PC, Huber SL, Herrler T, et al: Distinct populations of cancer stem cells determine tumor growth and metastatic activity in human pancreatic cancer. Cell Stem Cell 1: 313-323, 2007.

13. Liu R, Wang X, Chen GY, et al: The prognostic role of a gene signature from tumorigenic breast-cancer cells. N Engl J Med 356: 217-226, 2007.

14. Pang R, Law WL, Chu AC, et al: A subpopulation of CD26 cancer stem cells with metastatic capacity in human colorectal cancer. Cell Stem Cell 6: 603-615, 2010.

15. Cordenonsi M, Zanconato F, Azzolin L, et al: The Hippo transducer TAZ confers cancer stem cell-related traits on breast cancer cells. Cell 147: 759-772, 2011.

16. Kitayama J, Nagawa H, Tsuno N, et al: Laminin mediates tethering and spreading of colon cancer cells in physiological shear flow. Br J Cancer 80: 1927-1934, 1999.

17. Daemi N, Thomasset N, Lissitzky JC, et al: Anti-beta4 integrin antibodies enhance migratory and invasive abilities of human colon adenocarcinoma cells and their MMP-2 expression. Int J Cancer 85: 850-856, 2000.

18. Enns A, Gassmann P, Schlüter K, Korb T, Spiegel HU, Senninger $\mathrm{N}$ and Haier $\mathrm{J}$ : Integrins can directly mediate metastatic tumor cell adhesion within the liver sinusoids. J Gastrointest Surg 8: 1049-1059, 2004.

19. Dydensborg AB, Teller IC, Groulx JF, et al: Integrin alpha6Bbeta4 inhibits colon cancer cell proliferation and c-Myc activity. BMC Cancer 9: 223, 2009.

20. Sakthianandeswaren A, Christie M, D'Andreti C, et al: PHLDA1 expression marks the putative epithelial stem cells and contributes to intestinal tumorigenesis. Cancer Res 71: 3709-3719, 2011.

21. Robertson JH, Yang SY, Winslet MC and Seifalian AM: Functional blocking of specific integrins inhibit colonic cancer migration. Clin Exp Metastasis 26: 769-780, 2009.

22. Vanharanta S, Shu W, Brenet F, et al: Epigenetic expansion of VHL-HIF signal output drives multiorgan metastasis in renal cancer. Nat Med 19: 50-56, 2013.

23. Wu B, Chien EY, Mol CD, et al: Structures of the CXCR4 chemokine GPCR with small-molecule and cyclic peptide antagonists. Science 330: 1066-1071, 2010.

24. Murphy PM: Chemokines and the molecular basis of cancer metastasis. N Engl J Med 345: 833-835, 2001.
25. Liotta LA: An attractive force in metastasis. Nature 410: 24-25, 2001.

26. Müller A, Homey B, Soto H, et al: Involvement of chemokine receptors in breast cancer metastasis. Nature 410: 50-56, 2001.

27. Ikushima H, Todo T, Ino Y, Takahashi M, Miyazawa $\mathrm{K}$ and Miyazono K: Autocrine TGF-beta signaling maintains tumorigenicity of glioma-initiating cells through Sry-related HMG-box factors. Cell Stem Cell 5: 504-514, 2009.

28. Piccirillo SG, Reynolds BA, Zanetti N, et al: Bone morphogenetic proteins inhibit the tumorigenic potential of human brain tumour-initiating cells. Nature 444: 761-765, 2006.

29. Chirasani SR, Sternjak A, Wend P, et al: Bone morphogenetic protein-7 release from endogenous neural precursor cells suppresses the tumourigenicity of stem-like glioblastoma cells. Brain 133: 1961-1972, 2010

30. Lombardo Y, Scopelliti A, Cammareri P, et al: Bone morphogenetic protein 4 induces differentiation of colorectal cancer stem cells and increases their response to chemotherapy in mice. Gastroenterology 140: 297-309, 2011.

31. Haraguchi N, Ohkuma M, Sakashita H, et al: $133^{+} \mathrm{CD} 44^{+}$ population efficiently enriches colon cancer initiating cells. Ann Surg Oncol 15: 2927-2933, 2008.

32. Sussman NL, Eliakim R, Rubin D, Perlmutter DH, DeSchryverKecskemeti $\mathrm{K}$ and Alpers DH: Intestinal alkaline phosphatase is secreted bidirectionally from villous enterocytes. Am J Physiol 257: G14-G23, 1989.

33. Augeron $\mathrm{C}$ and Laboisse CL: Emergence of permanently differentiated cell clones in a human colonic cancer cell line in culture after treatment with sodium butyrate. Cancer Res 44: 3961-3969, 1984.

34. Jo M, Eastman BM, Webb DL, Stoletov K, Klemke R and Gonias SL: Cell signaling by urokinase-type plasminogen activator receptor induces stem cell-like properties in breast cancer cells. Cancer Res 70: 8948-8958, 2010.

35. Liao CP, Adisetiyo H, Liang M and Roy-Burman P: Cancerassociated fibroblasts enhance the gland-forming capability of prostate cancer stem cells. Cancer Res 70: 7294-7303, 2010.

36. Lathia JD, Gallagher J, Heddleston JM, et al: Integrin alpha 6 regulates glioblastoma stem cells. Stem Cell 6: 421-432, 2010. 